\title{
Poultry Litter for the Production and Quality of Enterolobium contortisiliquum Vell. Seedlings
}

\author{
Rodrigo Ferreira da Silva ${ }^{1}$ (D), Andre Luis Grolli ${ }^{2}$ (D), Paola Daiane Welter ${ }^{2}$ (D), \\ Clovis Orlando da $\operatorname{Ros}^{3}$ (D), Douglas Leandro Scheid ${ }^{4}$ \\ ${ }^{1}$ Universidade Federal de Santa Maria - UFSM, Frederico Westphalen/RS, Brasil \\ ${ }^{2}$ Departamento de Ciências Agronômicas e Ambientais, Universidade Federal de Santa Maria - UFSM, Frederico \\ Westphalen/RS, Brasil \\ ${ }^{3}$ Departamento de Ciências Agronômicas e Ambientais, Universidade Federal de Santa Maria - UFSM, Santa Maria/RS, \\ Brasil \\ ${ }^{4}$ Departamento de Solos, Universidade Federal de Santa Maria - UFSM, Santa Maria/RS, Brasil
}

\begin{abstract}
The objective of this work was to determine the efficiency of poultry litter ratios added to the commercial substrate and to peat in the growth and quality of Enterolobium contortisiliquum seedlings. The design was completely randomized, with 10 replications, in a $2 \times 5$ factorial arrangement with two substrates (peat and commercial substrate) and five poultry litter ratios, added (v:v) to both substrates (0, 25\%, 50\%,75\% and 100\%). The height, stem diameter, dry matter of shoot and roots, root specific surface area, Dickson quality index and NPK accumulated in dry matter of shoot and roots were evaluated. Poultry litter can be added up to a $35 \%$ ratio to the commercial substrate or to peat for the production of Enterolobium contortisiliquum seedlings; proportions above this, for both substrates, compromise the production. The treatments with peat provided lower growth and quality of Enterolobium contortisiliquum seedlings, compared to the commercial substrate.
\end{abstract}

Keywords: native species, organic compound, peat, commercial substrate. 


\section{INTRODUCTION}

In Brazil, mainly in the southern region of the country, to the detriment of intensive poultry farming, a large contingent of organic waste from poultry litter is produced (USDA, 2016). These residues, when properly managed, can serve as fertilizer, making it possible to partially replace the substrates used in the production of seedlings (Brugnara, 2014). Thus, scientific studies aimed at the proper use of such waste should be encouraged, in order to generate destination alternatives for this organic waste.

Enterolobium contortisiliquum Vell. (earpod tree) is a pioneer native tree species belonging to the Leguminosae family, occurring in the caatinga, cerrado and pampa biomes (Grings \& Brack, 2011). This species is recommended for the reforestation of degraded areas, permanent preservation and mixed plantations, mainly due to its rapid initial growth (Araujo \& Paiva, 2011), and its high capacity to overcome competition and to exploit soil by its root system (Marcuzzo et al., 2015).

The rapid initial growth of seedlings, when implanted on the field, also depends on the quality during the production stage (Abreu et al., 2015). Substrate is a factor that influences the quality of seedlings, since their physical and chemical characteristics depend on the types of materials used in its composition (Gasparin et al., 2014). The availability of nutrients in the substrate is also a factor to be considered: if there is a deficiency, they should be made available to seedlings (Uliana et al., 2014). Organic waste is an alternative in terms of substrate components for the production of forest seedlings; however, it is necessary to chemically characterize the residues for nutritional purposes, in order to guarantee the survival and growth of seedlings (Santos et al., 2014).

The use of organic waste derived from animal activity as a component for the formulation of substrates has become an alternative for environmental preservation, since when inappropriately destined, they can cause impacts to the environment (Santos et al., 2010). Poultry litter is an abundant organic waste because of the expansion of confined poultry production, which represents the optimal source of nutrients for plants, mainly nitrogen, phosphorus and potassium, and provides good physical properties for the substrate as well (Luz et al., 2009). Trazzi et al. (2013), while working with organic substrates, observed that the addition of $35 \%$ of poultry litter to the substrate presented a higher nutrient content in Tectona grandis seedlings. In a work using poultry litter mixed in the substrate, Torres et al. (2011) obtained a decreasing regression in the development of physic nut seedlings, with an increase in the development of the seedlings using $10 \%$ of poultry litter and a decrease as the proportion of the organic fertilizer increased. The use of $20 \%$ poultry litter favored the development and quality of Eucalyptus dunni Maiden seedlings. However, an increase in the ratios had a detrimental effect on germination and seedling survival (Menegatti et al., 2017). Thus, it is possible that poultry litter, or the addition of ratios of this residue in the formulation of substrates, allows a proper growth and nutrition of earpod tree seedlings.

Thus, this work aimed at determining the efficiency of poultry litter ratios added to commercial substrates and peat in promoting the growth and quality of Enterolobium contortisiliquum seedlings.

\section{MATERIAL AND METHODS}

The experiment was conducted for 120 days with Enterolobium contortisiliquum seedlings in a greenhouse $\left(28^{\circ} \mathrm{C}, 60 \%\right.$ humidity and photo period of $12 \mathrm{~h}$ ) belonging to the Instituto Federal Farroupilha de Frederico Westphalen, Rio Grande do Sul state, Brazil. Daily irrigations were performed based on the weighing of the experimental units, maintaining the humidity of the substrates at $80 \%$ of the field capacity.

The experimental design was completely randomized, with 10 replications, in a $2 \times 5$ factorial arrangement with two substrates (commercial substrate and peat) and five poultry litter ratios (0 (zero), 25\%, 50\%, $75 \%$ and $100 \%)$. Ratios were based on volume (v:v) of poultry litter over commercial substrate and peat. The used commercial substrate (CS) was from the Maxfertil" brand, composed of pinus bark, ashes, vermiculite and sawdust, and the poultry litter (PL) was obtained from a broiler chicken production aviary, collected after eight production lots.

After mixing the ratios of the poultry litter to the substrates (commercial and peat), samples were taken to perform the chemical characterization. The total N, P, K, Ca and Mg contents were extracted by digestion with sulfuric acid, and they were quantified 
by distillation and titration $(\mathrm{N})$, spectrophotometry $(\mathrm{P})$, flame photometry $(\mathrm{K})$ and atomic absorption spectrometry (Ca and $\mathrm{Mg}$ ) (Silva, 2009). $\mathrm{Cu}$ and $\mathrm{Zn}$ contents in the substrates were extracted by wet digestion with $\mathrm{HNO}_{3}+\mathrm{HClO}_{4}$ (3:1) and by determination in an atomic absorption spectrometry (Miyazawa et al., 2009). The determination of the organic carbon (OC) was based on the methodology described by Yeomans \& Bremner (1988) and the $\mathrm{pH}$ was determined according to the methodology by Silva (2009).

Sowing was carried out in May 2014, with three seeds per experimental unit and later thinning when seedlings presented a pair of definitive leaves. The experimental units were composed of polyethylene plastic bags, filled with $600 \mathrm{~cm}^{3}$ of substrate, containing one plant and one bag per replication. To overcome tegumentary dormancy, seeds were submitted to mechanical scarification, by breaking the tegument with pruning shears.

One-hundred and twenty days from sowing, the height of the shoot (S) was measured with a graduated ruler, from the plant stem to the caulinar apex; the stem diameter (SD) was measured with a digital caliper, with an accuracy of $0.01 \mathrm{~mm}$ and the dry matter of the shoot (SDM) and root section (RDM), after drying in an oven at $60 \pm 1{ }^{\circ} \mathrm{C}$, until constant weight. The dry matter was ground and, after that, the $\mathrm{N}, \mathrm{P}$ and $\mathrm{K}$ contents were determined using the methodologies mentioned in the characterization of the substrates. Based on the dry matter $\left(\mathrm{g} \mathrm{plant}^{-1}\right)$, the $\mathrm{N}, \mathrm{P}$ and $\mathrm{K}\left(\mathrm{mg} \mathrm{kg}^{-1}\right)$ contents of shoot and roots of the seedlings were calculated on the accumulated amount of nutrients, expressed as mg plant ${ }^{-1}$.

The specific surface area (SSA) of the roots was estimated according to the methodology of Tennant (1975) and the quality of the seedlings was estimated by the Dickinson quality index, according to the equation $\mathrm{DQI}=\mathrm{TDM}(\mathrm{g}) /[\mathrm{S}(\mathrm{cm}) / \mathrm{SD}(\mathrm{mm})]+[\mathrm{SDM}(\mathrm{g}) / \mathrm{RDM}(\mathrm{g})]$ (Dickson et al., 1960).

The results were submitted to analysis of variance and when they showed a significant interaction, the effects of the qualitative factor (substrate) within each level of the quantitative factor (poultry litter ratio) were analyzed. The means of the qualitative factor were compared by $\mathrm{F}$ test, whereas those of the quantitative factor were compared by regression analysis. When there was no significant interaction, the simple effects of each variation factor were analyzed, the qualitative one by $\mathrm{F}$ test, and the quantitative one by regression analysis. For the statistical analysis, the SISVAR (Ferreira, 2011) program was used, based on significance levels above 95\% ( $\mathrm{p} \leq 0.05)$. As for the variables that presented quadratic equations, the point of maximum or minimum response to the application of poultry litter ratios added to the peat and to the commercial substrate was calculated.

\section{RESULTS AND DISCUSSION}

Results showed a significant interaction between the variation factors, substrates (commercial and peat) and poultry litter ratios for the morphological and quality parameters of the seedlings (Figure 1). The regression equations, adjusted with the poultry litter ratios added to the commercial substrate and the peat, were quadratic in all evaluated parameters, indicating the existence of an adequate ratio of poultry litter that enhances the growth and quality of seedlings. However, in the $100 \%$ ration of poultry litter, plant development did not occur, resulting in their death.

The addition of $35 \%$ and $30 \%$ of poultry litter to the commercial substrate and $28 \%$ and $32 \%$ to peat provided higher height and diameter of the seedlings, respectively (Figure 1A, 1B). In a study with tamarind seedlings (Tamarindus indica L.), Pereira et al. (2010) also found a higher growth in the height and stem diameter of seedlings with $37 \%$ and $46 \%$ of poultry litter added to the commercial substrate. The authors justified the higher growth of the seedlings with the better physical and biological conditions provided by the addition of the poultry litter to the commercial substrate.

The highest shoot dry matter production was observed at the ratios of $37 \%$ of poultry litter added to the commercial substrate, and $43 \%$ of poultry litter mixed with peat (Figure 1C). Trazzi et al. (2013) found the highest average of shoot dry matter in teak seedlings (Tectona grandis Linn), in the treatment consisting of $25 \%$ of commercial substrate, $40 \%$ of subsoil soil and $35 \%$ of poultry litter. The authors report that the dry matter increase with the addition of poultry litter may be related to the greater availability of nutrients and the adequate retention of water and aeration 
that the poultry litter provides when mixed with the commercial substrate.

Torres et al. (2011) verified that as poultry litter concentrations increased, there was a smaller biomass increment of physic nut seedlings (Jatropha curcas L.) due to the drainage that affected the aeration of the root system, similarly to what was found by Silva et al. (2012) in coffee seedlings (Coffea arabica L.) with less expressive results in most evaluated growth parameters with the proportion of $60 \%$ of poultry litter in the commercial substrate.
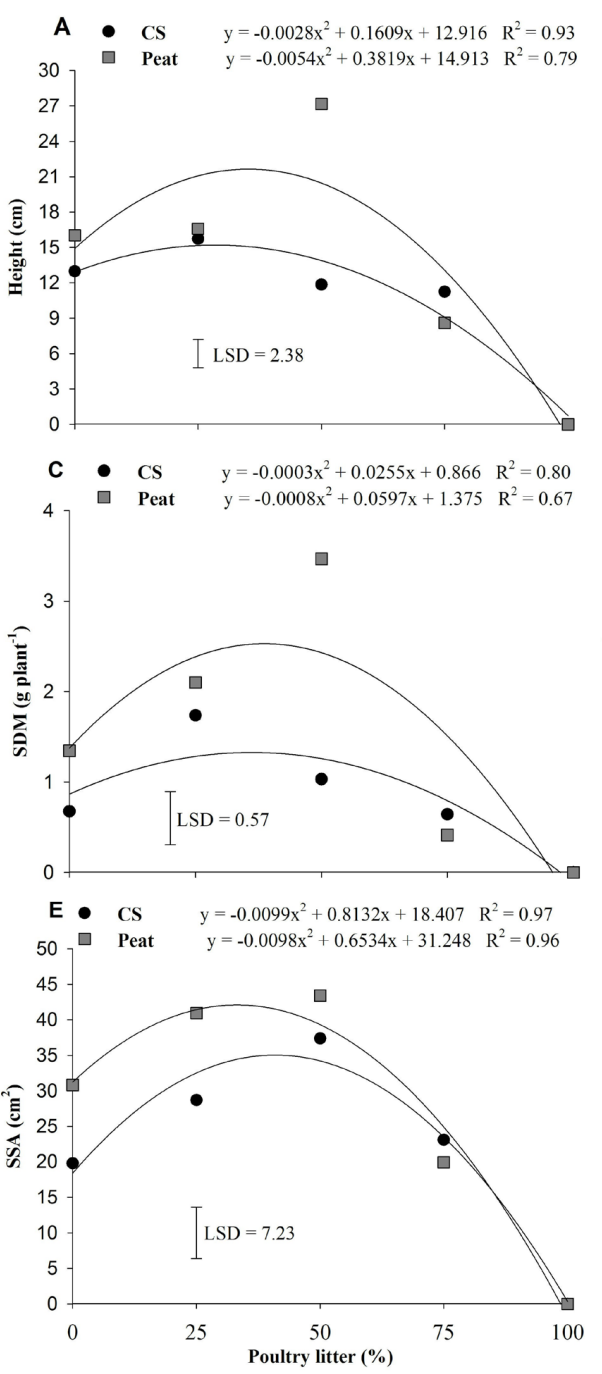

Root dry matter production was higher with the $38 \%$ poultry litter ratio added to the commercial substrate, and $31 \%$ of poultry litter in the peat (Figure 1D). This result corroborates those of Costa et al. (2008) who, working with organic and mineral fertilization, observed that poultry litter provided higher dry biomass production by the roots of lemon grass (Cymbopogon citratus) seedlings because, according to Torres et al. (2011), poultry litter, when used in adequate quantities, can be a source of nutrients.

The specific surface area of the roots of earpod tree seedlings was higher with the poultry litter mix at a ratio
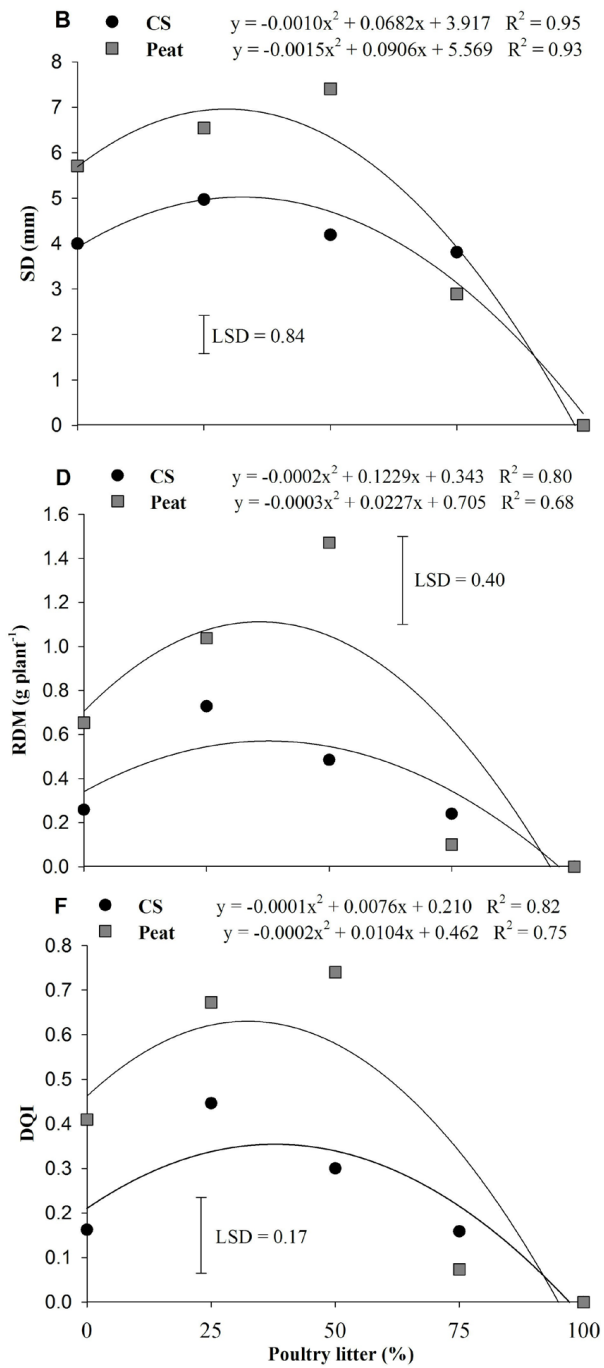

Figure 1. Regression equations for the height of seedlings (A), stem diameter - SD (B), shoot dry matter - SDM (C), root dry matter - RDM (D), specific surface area - SSA (E), Dickson quality index - DQI (F) of Enterolobium contortisiliquum Vell. seedlings according to the poultry litter ratio added to peat and to the commercial substrate (CS). LSD: Least significant difference between poultry litter ratio added to peat and to the commercial substrate. 
of $33 \%$ and $41 \%$ in the commercial substrate and in the peat, respectively (Figure 1E). Macedo et al. (2011) mention the higher availability of nutrients as a factor that is responsible for the higher root growth of white ipê (Tabebuia roseoalba) on substrates with soil or sand mixed with semi-decomposed poultry litter. Thus, the increase of the root specific surface area, added to the increase in the root dry matter with the addition of organic compound, in this case poultry litter at the proper ratio, allows greater root expansion, with the production of fine roots, providing greater absorption of water and nutrients (Kiehl, 2008).

The quality of the seedlings evaluated by the seedling quality index (DQI) was higher with the use of $26 \%$ and $38 \%$ of poultry litter in the commercial substrate and in peat, respectively (Figure 1F). The DQI is a good indicator of seedling quality, since in its calculation the robustness and the balance of biomass distribution between shoot and root are considered, and the higher the DQI value, the better the seedling quality standard (Vidal et al., 2006).

The reduction of growth and quality of the seedlings with the addition of poultry litter to the commercial substrate and to peat, above the values of maximum technical efficiency (average proportion of 35\%), and the non-survival of seedlings with the use of $100 \%$ poultry litter, can be related to oxygen consumption by the microorganisms in the process of decomposition of the unstable organic material found in the poultry litter, affecting the germination of seeds and the growth of seedlings (Torres et al., 2011).
Salinity due to an excess of salts in the poultry litter is another factor that may have affected the germination and growth of seedlings, as justified by Brugnara et al. (2014) in passion fruit seedlings (Passiflora edulis) with the addition of $24 \%$ of poultry litter to the commercial substrate. The high concentration of leaves causes osmotic effect and nutritional imbalance due to the high ionic concentration (Schossler et al., 2012), which may be the factor that influenced the growth reduction of seedlings above the average ratio of $35 \%$ of poultry litter added to the commercial substrate and to peat, even with the proportional increase of the amount of macronutrients with the use of poultry litter (Table 1).

The amounts of N, P and K accumulated in the shoot and roots of earpod tree seedlings showed a significant interaction between the variation factors, substrates (commercial and peat) and poultry litter ratios, with the adjustment of quadratic regression equations (Figure 2). It is worth mentioning that the poultry litter ratios that conditioned the highest accumulated amounts of nutrients in the shoot and root dry matter were similar to the ratios that contributed to the maximum growth and quality of earpod tree seedlings.

The maximum accumulation of $\mathrm{N}, \mathrm{P}$ and $\mathrm{K}$ was between $33 \%$ and $41 \%$ of poultry litter added to the commercial substrate and to peat (Figure 2). The increase in the amount of accumulated nutrients up to these poultry litter ratios may be related to the increase in the availability of N, P and $\mathrm{K}$ in the substrate (Table 1).

Table 1. Chemical characterization of commercial substrate and peat after the addition of poultry litter ratios for the production of Enterolobium contortisiliquum Vell seedlings.

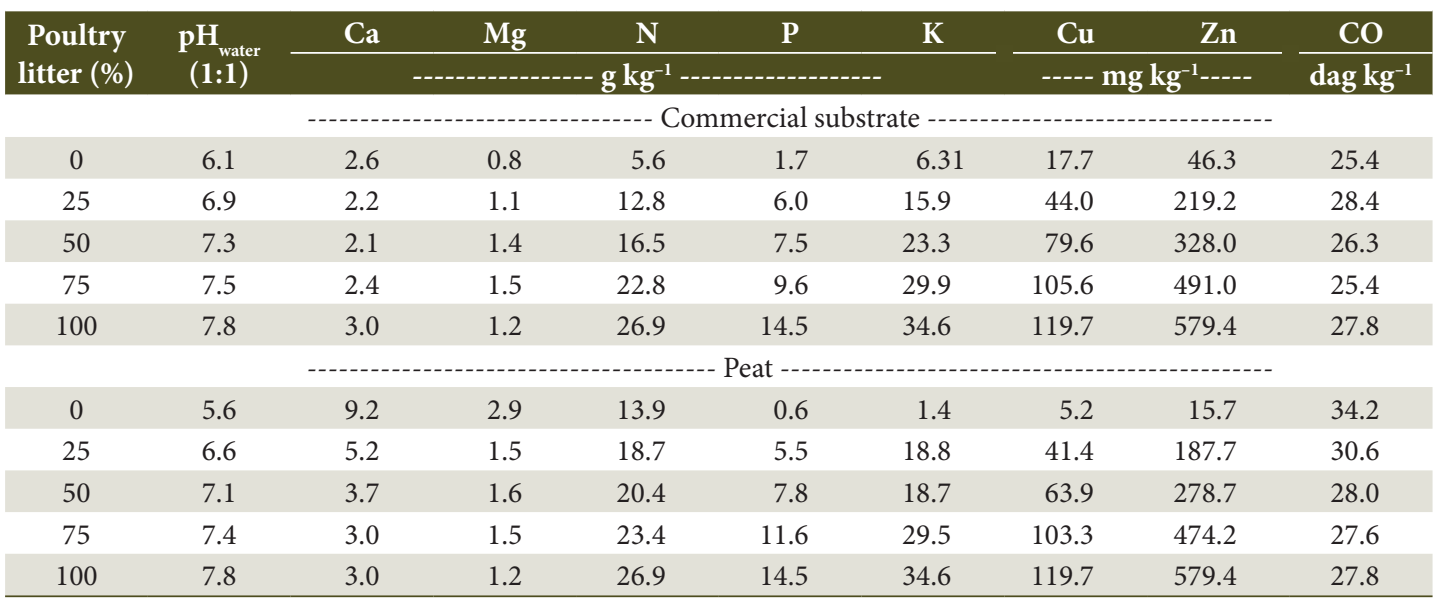



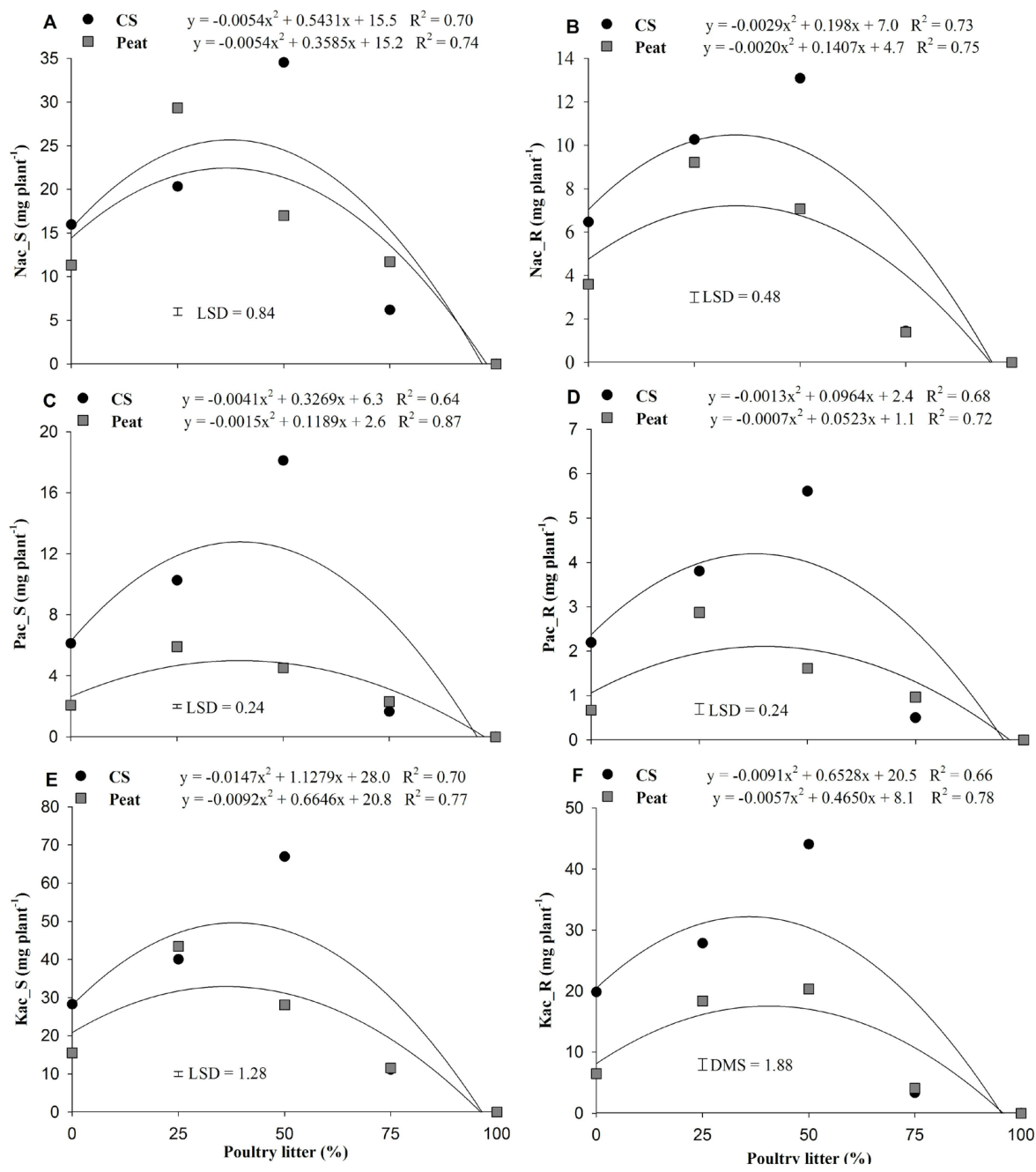

Figure 2. Regression equation for the quantity of accumulated N (Nac_S) (A), accumulated P (Pac_S) (C) and accumulated K (Kac_S) (E) in the shoot dry matter and for the quantity of accumulated N (Nac_R) (B), accumulated P (Pac_R) (D) and accumulated K (Kac_R) (F) in the root dry matter of earpod tree seedlings according to the poultry litter ratios added to peat and to the commercial substrate (CS). LSD: Least significant difference between poultry litter ratio added to peat and to the commercial substrate.

The availability of nutrients to plants is directly related to the absorbed amount, since according to Lavres et al. (2005), when determining the levels of macronutrients in castor bean (Ricinus communis L.) cultivated in nutrient solutions and with nutritional restrictions, the highest nutrient intake in cultivated plants occurred in more nutritious media. However Severino et al. (2008), when evaluating the growth and macronutrient content of castor bean plants on five organic substrates, did not reach significance among the average values of nutrients in plants with the amount contained in the substrates. The authors concluded that some substrates with high nutrient contents may not provide adequate growth conditions for certain plant species, thus impairing nutrient accumulation, which may have occurred at doses above the maximum technical efficiency in this study.

The study of the correlation between the variables analyzed in this study and the nutrient amounts found in the different ratios of poultry litter added to the commercial substrate and to peat indicated significant but negative coefficients in most correlations (Table 2). 
Table 2. Correlation coefficient between the analyzed variables with the nutrient amounts found in the different ratios of poultry litter added to commercial substrate and peat.

\begin{tabular}{|c|c|c|c|c|c|c|c|}
\hline \multirow{2}{*}{ Analyzed variables ${ }^{(1)}$} & $\mathrm{Ca}$ & Mg & $\mathbf{N}$ & $\mathbf{P}$ & $\mathbf{K}$ & $\mathbf{C u}$ & Zn \\
\hline & \multicolumn{7}{|c|}{ 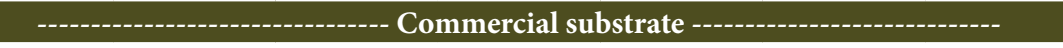 } \\
\hline SD & $-0.83^{*}$ & -0.15 & $-0.72^{*}$ & $-0.74^{*}$ & $-0.66^{*}$ & $-0.67^{*}$ & $-0.71^{*}$ \\
\hline Height & $-0.82^{*}$ & -0.01 & $-0.60^{*}$ & $-0.62^{*}$ & $-0.52^{*}$ & $-0.52^{*}$ & $-0.58^{*}$ \\
\hline SDM & $-0.73^{*}$ & 0.04 & $-0.44^{*}$ & $-0.43^{\star}$ & $-0.37^{\star}$ & $-0.38^{\star}$ & $-0.43^{*}$ \\
\hline $\mathrm{RDM}$ & $-0.60^{*}$ & -0.04 & $-0.42^{*}$ & $-0.40^{\star}$ & $-0.37^{\star}$ & $-0.38^{*}$ & $-0.42^{\star}$ \\
\hline SSA & $-0.82^{\star}$ & -0.08 & $-0.64^{*}$ & $-0.67^{\star *}$ & $-0.59^{*}$ & $-0.60^{*}$ & $-0.63^{*}$ \\
\hline DQI & $-0.67^{*}$ & -0.14 & $-0.54^{*}$ & $-0.51^{\star}$ & $-0.49^{*}$ & $-0.52^{*}$ & $-0.54^{*}$ \\
\hline Nac_PA & $-0.72^{\star}$ & 0.02 & $-0.48^{*}$ & $-0.48^{\star}$ & $-0.41^{\star}$ & $-0.41^{\star}$ & $-0.47^{\star}$ \\
\hline Nac_R & $-0.57^{\star}$ & -0.04 & $-0.42^{\star}$ & $-0.41^{\star}$ & $-0.37^{\star}$ & $-0.38^{*}$ & $-0.42^{*}$ \\
\hline Pac_PA & $-0.72^{\star}$ & 0.07 & $-0.40^{*}$ & $-0.39^{\star}$ & $-0.33^{\star}$ & $-0.34^{*}$ & $-0.4^{*}$ \\
\hline Pac_R & $-0.61^{\star}$ & -0.01 & $-0.39^{*}$ & $-0.38^{\star}$ & $-0.34^{*}$ & $-0.36^{*}$ & $-0.39^{*}$ \\
\hline Kac_PA & $-0.74^{*}$ & 0.05 & $-0.45^{*}$ & $-0.45^{\star}$ & $-0.38^{*}$ & $-0.39^{\star}$ & $-0.44^{*}$ \\
\hline \multirow{2}{*}{ Kac_R } & $-0.58^{*}$ & -0.04 & $-0.41^{*}$ & $-0.40^{\star}$ & $-0.36^{*}$ & $-0.37^{\star}$ & $-0.41^{*}$ \\
\hline & \multicolumn{7}{|c|}{ 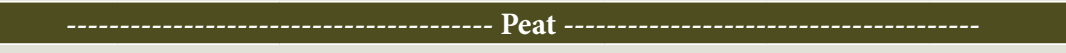 } \\
\hline SD & $0.35^{\star}$ & $0.35^{\star}$ & $-0.66^{*}$ & $-0.64^{\star}$ & $-0.56^{*}$ & $-0.63^{\star}$ & $-0.66^{*}$ \\
\hline Height & $0.44^{\star}$ & $0.41^{\star}$ & $-0.74^{\star}$ & $-0.72^{\star}$ & $-0.62^{\star}$ & $-0.70^{*}$ & $-0.73^{\star}$ \\
\hline SDM & 0.16 & 0.03 & $-0.43^{*}$ & $-0.43^{*}$ & $-0.31^{*}$ & $-0.45^{\star}$ & $-0.47^{\star}$ \\
\hline RDM & 0.12 & -0.01 & $-0.39^{*}$ & $-0.40^{\star}$ & -0.28 & $-0.42^{\star}$ & $-0.43^{*}$ \\
\hline SSA & 0.09 & 0.13 & $-0.46^{*}$ & $-0.44^{*}$ & $-0.39^{*}$ & $-0.43^{*}$ & $-0.47^{\star}$ \\
\hline DQI & 0.12 & 0.01 & $-0.4^{\star}$ & $-0.41^{\star}$ & -0.29 & $-0.43^{\star}$ & $-0.45^{\star}$ \\
\hline Nac_PA & 0.22 & 0.05 & $-0.43^{*}$ & $-0.44^{\star}$ & -0.30 & $-0.45^{\star}$ & $-0.46^{*}$ \\
\hline Nac_R & 0.23 & 0.08 & $-0.41^{*}$ & $-0.42^{\star}$ & -0.29 & $-0.44^{*}$ & $-0.44^{\star}$ \\
\hline Pac_PA & 0.07 & -0.03 & $-0.36^{*}$ & $-0.36^{*}$ & -0.23 & $-0.37^{*}$ & $-0.39^{*}$ \\
\hline Pac_R & 0.05 & -0.09 & -0.30 & $-0.31^{\star}$ & -0.19 & $-0.34^{*}$ & $-0.35^{\star}$ \\
\hline Kac_PA & 0.16 & 0.01 & $-0.40^{*}$ & $-0.41^{\star}$ & -0.27 & $-0.42^{*}$ & $-0.43^{*}$ \\
\hline Kac_R & 0.09 & -0.03 & -0.30 & -0.30 & -0.17 & $-0.31^{*}$ & $-0.32^{*}$ \\
\hline
\end{tabular}

${ }^{(1)}$ SD: stem diameter; SDM: shoot dry matter; RDM: root dry matter; SSA: specific surface area; DQI: Dickson quality index; Nac_PA: N accumulated in the shoot; Nac_R: N accumulated in the root; Pac_PA: P accumulated in the shoot; Pac_R: P accumulated in the root; Kac_PA: K accumulated in the shoot; Kac_R: K accumulated in the root; ${ }^{*}$ Significant values at $5 \%$ probability of error.

In the case of the $\mathrm{N}, \mathrm{P}$ and $\mathrm{K}$ quantities found in the poultry litter, the negative values of correlation coefficient should be analyzed with caveats, since the increase in the quantity of these nutrients with the use of poultry litter should not provide an unfavorable environment to the growth of plants.

$\mathrm{N}$ is a macronutrient required in high amounts by plants, since it participates in metabolic processes as a constituent of proteins, nucleic acids, chlorophylls, coenzymes, phytohormones and secondary metabolites, directly influencing the growth and development of plants (Marschner, 2011). $\mathrm{K}$ is one of the most abundant cations in plants, and is responsible for the performance of important physiological functions such as photosynthesis, osmoregulation, enzymatic activities, protein synthesis and maintenance of plasma membrane potential (Hafsi et al., 2014). P is one of the main structural elements of plants, since they make up macromolecules components of nucleic acids which, like DNA, carry genetic codes, besides being the main energetic currency of the cell, the ATP (Marschner, 2011; Taiz et al., 2017).

Despite the similar poultry litter ratio that conditioned the maximum growth, quality and quantity of nutrients accumulated in the seedlings, the use of peat presented a lower growth potential compared to the commercial substrate, because the highest values in all evaluated parameters, both without the addition of poultry litter and at the dose of maximum technical efficiency, were higher with the commercial substrate (Figure 1 and Figure 2). In addition, the increases in 
height and dry matter of shoot and roots were smaller with the poultry litter ratios added to peat.

The higher amounts of N, P and K accumulated in earpod tree seedlings with the use of the commercial substrate, in comparison to peat, are not solely related to the amounts of nutrients found in the substrates, because at the ratios of maximum technical efficiency, the amounts of nutrients were similar (Table 1). The higher $\mathrm{pH}$ of the commercial substrate (6.1), which is in the range of 6.0 to 7.0 and considered ideal for substrates (Kämpf, 2000), in relation to the $\mathrm{pH}$ of peat (5.6), may be another factor that conditioned the greater growth of seedlings. However, with the addition of poultry litter to the commercial substrate and to peat, nutrients were added and the $\mathrm{pH}$ value increased, indicating that the difference in growth parameters between the two substrates is not solely associated with acidity and nutrient availability. In this sense, Lima et al. (2006) emphasize the high amount of nutrients in the poultry litter; however, they emphasize the importance of incorporating it to material with good physical characteristics, to promote a chemically and physically suitable substrate, thus promoting greater growth and nutritional contribution to plants.

On average, values of $33 \%$ of poultry litter addition to the commercial substrate and of $35 \%$ to peat were the ratios that conditioned better responses in seedlings production. In relation to the accumulated amount of $\mathrm{N}, \mathrm{P}$ and $\mathrm{K}$ in the dry matter of shoot and roots, the average of the adequate poultry litter ratio was equal for both substrates, with a value of $37 \%$. These values indicate that the growth, quality and quantity of nutrients accumulated in the earpod tree seedlings were potentiated with a similar ratio of poultry litter, where the average value of $35 \%$ of poultry litter could be used both for the commercial substrate and for peat.

\section{CONCLUSIONS}

Poultry litter can be used in the composition of substrates for the production of earpod tree seedlings at the ratio of $35 \%$ in a mixture with commercial substrate or peat. Ratios above this, for both substrates, compromise the development and survival of the seedlings.
Peat provides lower growth and quality of earpod tree seedlings compared to the commercial substrate, when used alone or mixed with poultry litter.

\section{SUBMISSION STATUS}

Received: 28 jan., 2017

Accepted: 16 nov., 2017

\section{CORRESPONDENCE TO}

\section{Paola Daiane Welter}

Departamento de Ciências Agronômicas e Ambientais, Universidade Federal de Santa Maria - UFSM, Linha 7 de Setembro, s/n, CEP 98400-000, Frederico Westphalen, RS, Brasil e-mail: pdaianew@hotmail.com

\section{FINANCIAL SUPPORT}

The authors thank the Brazilian agency CAPES (Coordination for the Improvement of Higher Education Personnel) for scholarship support and UFSM (Federal University of Santa Maria) for provide the physical space to conduct the experiments.

\section{REFERENCES}

Abreu AHM, Leles PSS, Melo LA, Ferreira DHAA, Monteiro FAS. Produção de mudas e crescimento inicial de Enterolobium contorsiliquum produzidas em diferentes recipientes. Floresta 2015; 45(1): 141-150. http://dx.doi. org/10.5380/rf.v45i1.28931.

Araujo A, Paiva S So. Germinação e produção de mudas de tamboril (E. contortisiliquum (Vell.) Morong) em diferentes substratos. Revista Árvore 2011; 35(3): 581-588. http://dx.doi.org/10.1590/S0100-67622011000400001.

Brugnara EC, Nesi CN, Verona LAF. Cama de aviário e composto de dejetos suínos em substratos para mudas de maracujazeiro-amarelo. Científica (Jaboticabal) 2014; 42(3): 242-251. http://dx.doi.org/10.15361/1984$5529.2014 \mathrm{v} 42 \mathrm{n} 3 \mathrm{p} 242-251$.

Brugnara EC. Cama de aviário em substratos para mudas de maracujazeiro-amarelo. Revista Brasileira de Agroecologia 2014; 9(3): 21-30.

Costa LCB, Rosal LF, Pinto JEBP, Bertolucci SKV. Efeito da adubação química e orgânica na produção de biomassa e óleo essencial em capim-limão (DC.) Stapf. Revista Brasileira de Plantas Medicinais 2008; 10(1): 16-20. 
Dickson A, Leaf AL, Hosner JF. Quality appraisal of white spruce and white pine seedling stock in nurseries. Forestry Chronicle 1960; 36(1): 10-13. http://dx.doi.org/10.5558/ tfc36010-1.

Ferreira DF. Sisvar: a computer statistical analysis system. Ciência e Agrotecnologia 2011; 35(6): 1039-1042. http:// dx.doi.org/10.1590/S1413-70542011000600001.

Gasparin E, Avila AL, Araujo MM, Cargnelutti A Fo, Dorneles DU, Foltz DRB. Influência do substrato e volume de recipiente na qualidade das mudas Cabralea canjerana (Vell.) Mart. em viveiro e no campo. Ciência Florestal 2014; 24(3): 553-563. http://dx.doi.org/10.5902/1980509815731.

Grings M, Brack P. Espécies madeireiras. Plantas para o futuro. In: Coradin L, Siminski A, Reis A, organizadores. Espécies Nativas da Flora Brasileira de Valor Econômico Atual ou Potencial Região Sul. Brasília: Ministério do Meio Ambiente; 2011.

Hafsi C, Debez A, Abdelly C. Potassium deficiencey in plants: effects and signaling cascades. Acta Physiologiae Plantarum 2014; 36(5): 1055-1070. http://dx.doi.org/10.1007/ s11738-014-1491-2.

Kämpf NA. Produção comercial de plantas ornamentais. Guaíba: Agropecuária; 2000.

Kiehl EJ. Adubação orgânica: 500 perguntas e respostas. 2. ed. Piracicaba: Ed. Degaspari; 2008.

Lavres J Jr, Boaretto RM, Silva MLSS, Correia D, Cabral CP, Malavolta E. Deficiências de macronutrientes no estado nutricional da mamoneira cultivar Iris. Pesquisa Agropecuária Brasileira 2005; 40(2): 145-151. http://dx.doi. org/10.1590/S0100-204X2005000200007.

Lima RLS, Severino LS, Silva MIL, Jerônimo JF, Vale LS, Beltrão NEM. Substratos para produção de mudas de mamoneira compostos por misturas de cinco fontes de matéria orgânica. Ciência e Agrotecnologia 2006; 30(3): 474479. http://dx.doi.org/10.1590/S1413-70542006000300013.

Luz JMQ, Morais TPS, Blank AF, Sodré ACB, Oliveira GS. Teor, rendimento e composição química do óleo essencial de manjericão sob doses de cama de frango. Horticultura Brasileira 2009; 27(3): 349-353. http://dx.doi.org/10.1590/ S0102-05362009000300016.

Macedo MC, Rosa YBCJ, Rosa EJ Jr, Scalon SPQ, Tatara MB. Produção de mudas de Ipê Branco em diferentes substratos. Cerne. Lavras 2011; 17(1): 95-102.

Marcuzzo SB, Araujo MM, Gasparin E. Plantio de espécies nativas para restauração de áreas em unidades de conservação: um estudo de caso no sul do Brasil. Floresta 2015; 45(1): 129-140. http://dx.doi.org/10.5380/ rf.v45i1.32763.

Marschner P. Mineral Nutrition of Higher Plants. Amsterdam: Elsevier/Academic Press; 2011.

Menegatti A, Arruda GOSF, Nesi CN. O adubo de cama de aviário na produção e na qualidade de mudas de
Eucalyptus dunnii Maiden. Revista Scientia Agraria 2017; 18(1): 43-49. http://dx.doi.org/10.5380/rsa.v18i1.50741.

Miyazawa M, Pavan MA, Muraoka T, Carmo CAFS, Melo WJ. Análise química de tecido vegetal. In: Silva FC. Manual de análises químicas de solos, plantas e fertilizantes. Brasília: Embrapa Informação Tecnológica; 2009. p. 59-85.

Pereira PC, Melo B, Freitas RS, Tomaz MA, Freitas CJP. Mudas de tamarindeiro produzidas em diferentes níveis de matéria orgânica adicionada ao substrato. Revista Verde de Agroecologia e Desenvolvimento Sustentável 2010; 5(3): 152-159.

Santos FEV, Kunz SH, Caldeira MVW, Azevedo CHS, Rangel OJPV. Características químicas de substratos formulados com lodo de esgoto para produção de mudas florestais. Revista Brasileira de Engenharia Agrícola e Ambiental 2014; 18(9): 971-979. http://dx.doi.org/10.1590/18071929/agriambi.v18n09p971-979.

Santos JF, Grangeiro JIT, Oliveira MEC. Produção da cultura da mamoneira em função da fertilização com cama de galinha. Engenharia Ambiental 2010; 7(1): 169-180.

Schossler TR, Machado DM, Zuffo AM, Andrade FR, Piauilino AC. Salinidade: efeitos na fisiologia e na nutrição mineral de plantas. Enciclopédia Biosfera 2012; 8(15): 1563-1578.

Severino LS, Lima RLS, Beltrão NEM, Sampaio LR. Crescimento e teor de macronutrientes em mudas de mamoneira cultivadas em cinco substratos orgânicos. Revista de Biologia e Ciências da Terra 2008; 8(1): 120-125.

Silva CJ, Silva CA, Melo B, Freitas CA. Produção de mudas de cafeeiro com adição de material orgânico em substrato comercial. Revista Verde de Agroecologia e Desenvolvimento Sustentável 2012; 7: 137-148.

Silva FC. Manual de análises químicas de solos, plantas e fertilizantes. 2. ed. Brasília: Embrapa Informação Tecnológica; 2009.

Taiz ZL, Zeiger E, Møller IM, Murphy A. Fisiologia vegetal. 5. ed. Porto Alegre: Artmed; 2017. 858 p.

Tennant D. A test a modified line intersect method of estimating root length. Journal of Ecology 1975; 63(3): 995-1001. http://dx.doi.org/10.2307/2258617.

Torres GT, Vendruscolo MC, Santi A, Soares VM, Pereira PSX. Desenvolvimento de mudas de pinhão manso sob diferentes doses de cama de frango no substrato. Revista Verde 2011; 6(4): 244-250.

Trazzi PA, Caldeira MVW, Passos RR, Gonçalves EO. Substratos de origem orgânica para produção de mudas de Teca (Tectona grandis Linn. F.). Ciência Florestal 2013; 23(3): 401-409. http://dx.doi.org/10.5902/1980509810551.

Uliana MB, Fey R, Malavasi MM, Malavasi UC. Produção de mudas de Anadenanthera Macrocarpa em função de substratos alternativos e da frequência de fertirrigação. Floresta 2014; 44(2): 303-312. http://dx.doi.org/10.5380/ rf.v44i2.31412. 
United States Department of Agriculture Estados Unidos - USDA. Livestock and poltry: world markets and trade. USA: USDA; 2016.

Vidal LHI, Souza JRP, Fonseca EP, Bordin I. Qualidade de mudas de guaco produzidas por estaquia em casca de arroz carbonizada com vermicomposto. Horticultura
Brasileira 2006; 24(1): 26-30. http://dx.doi.org/10.1590/ S0102-05362006000100006.

Yeomans JC, Bremner JMA. Rapid and precise method for routine determination of carbono in soil. Plant Analysis 1988; 19(13): 1467-1476. http://dx.doi. org/10.1080/00103628809368027. 